\title{
Diversidade na Ciência, um Café e um Pastel de Nata por Cristina Delerue-Matos
}

Vivemos um período nunca imaginado. Obrigados a estar isolados, confinados, apenas conseguimos comunicar porque o desenvolvimento científico e tecnológico colocou ao nosso alcance ferramentas que tornam possível a liģação entre todos. A distância deixou de ter o mesmo significado e conseguimos estar todos juntos, cada um no seu local de residência, unidos em família, ligados por profissões, pela amizade, misturando gerações, culturas, origens e experiências.

Desde março de 2020, data em que fomos confrontados com a pandemia COVID-19, participamos num sem número de iniciativas à distância de um clique, procurando manter-nos ativos, acompanhar o desenrolar dos acontecimentos e continuar a ser intervenientes no Mundo que continua a existir fora de portas.

Tudo parece ter mudado. A comunicação torna-se prioritária e o saber comunicar à distância, uma competência valorizada. Multiplicam-se as iniciativas online, e quando damos conta os horários alargados fizeram os dias ficar mais pequenos, as pausas para um café foram eliminadas e os fins de semana tornaram-se iguais aos restantes dias de trabalho. As tarefas parecem não ter fim e os prazos dificilmente são cumpridos.

Em 2020 a Ciência é enaltecida. É dela que surge o conhecimento necessário para lidar com o novo vírus. Médicos e investigadores de todo o mundo têm concentrado esforços e saberes na procura de uma resposta à pandemia, com um nível de colaboração sem precedentes. 0 aparecimento da vacina para combater o coronavírus, desenvolvida em tempo recorde, traz confiança no futuro e a esperança de dias melhores.

Foi nesta nova e recente realidade que a IUPAC nos convidou, mais uma vez, a participar no Global Women's Breakfast (GWB; iupac.org/gwb). Este evento visa estabelecer uma rede virtual em que as mulheres com formação e atividade profissional na área da Química, se encontram e partilham as suas preocupações, sucessos e aspirações profissionais. 0 GWB é aberto à participação de todo o tipo de organizações científicas, educacionais e industriais, assim como sociedades científicas e organizações governamentais. Unidos pela Química, o objetivo comum é aproximar os participantes através da partilha de conhecimentos e competências, na procura de um Mundo mais pacífico, próspero e sustentável. A título individual ou em grupo, todos têm lugar.

0 pequeno almoço é um pretexto. 0 tema de 2021 centra-se em Empowering Diversity in Science. Esta iniciativa GWB teve uma primeira edição em 2011 sob o tema Women Sharing a Chemical Moment in Time - Networking Breakfast. No centésimo aniversário da IUPAC e centésimo quinquagésimo aniversário da Tabela Periódica em 2019, a iniciativa foi reavivada. Em torno do tema Empowering Women in Chemistry: A Global Networking Event, o pequeno almoço reuniu cientistas de todo o Mundo. Empowering and Educating foi o tema selecionado na edição de 2020. 0 sucesso dos GWB evidenciou a necessidade de construir uma rede de investigadores que trabalhem juntos, contribuindo para o cumprimento dos Objetivos de Desenvolvimento Sustentável.

Condicionados pelo confinamento, a participação acarreta desafios ainda maiores, mas a vontade de acenar que somos resilientes fez com que a SPQ se associasse ao GWB criando o menu com marca Portugal: um café e um pastel de nata.

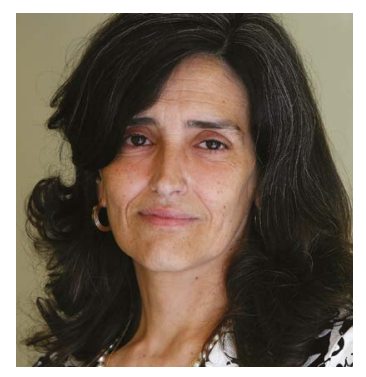

\section{Cristina Delerue-Matos}

Professora Coordenadora Principal do Instituto Superior de Engenharia do Porto (ISEP), Politécnico do Porto, coordenadora do grupo de Química Ambiental da unidade de investigação Laboratório Associado para a Química Verde (LAQV) e do Grupo de Reação e Análises Químicas do ISEP. Representante de
Portugal na VI Divisão da IUPAC- Química e Ambiente. As suas áreas de interesse científico são a Química Analítica, a Eletroanalítica, a monitorização de poluentes, a remediação de águas e solos e a segurança alimentar.

cmm@isep.ipp.pt

ORCID.org/0000-0002-3924-776X 